administered by the Company : Dr. L. J. P. Duncan, lecturer in therapeutics, University of Edinburgh; and Dr. R. F. Mahler, lecturer in therapeutics, University of St. Andrews.

\section{Ramsay Memorial Fellowship Awards}

The Ramsay Memorial Fellowships Trustees have awarded fellowships in chemistry for 1957-58 as follow : Mr. T. E. Peacock, a general fellowship at the University College of North Staffordshire ; a Glasgow fellowship to Mr. J. K. Sutherland at the Imperial College of Science and Technology, London; a Canadian fellowship to Dr. D. McK. Wiles, at the University of Leeds; a Japanese fellowship to Mr. M. Masui, at University College, London; a New Zealand fellowship to Mr. J. E. Fergusson, at University College, London; Spanish fellowships to Mr. P. Arambarri, at Rothamsted Experimental Station, and to Mr. D. Rodriguez, at the University of Sheffield ; a Swiss fellowship to Dr. R. Hümbelin, at University College, London. The Trustees have renewed the following fellowships for the same year : Dr. M. J. Stephen (general fellowship), at the University of Cambridge; Dr. G. S. Harris (Glasgow fellowship), at the University of Cambridge; Mr. C. H. Stam (Netherlands fellowship), at the University of Leeds; Dr. J. R. Villanueva (Spanish fellowship), at the University of Cambridge.

\section{Conference on Industrial Carbon and Graphite}

THE Society of Chemical Industry is to hold a three-day Conference on "Industrial Carbon and Graphite" at the William Beveridge Hall, University of London, W.C.1, during September 24-26. Many countries, including the United States, the U.S.S.R., France and the Netherlands, will be represented, and more than fifty papers have been submitted. Carbon and graphite provide a wide and important field of study, especially in nuclear energy and electrical applications. Papers will be preprinted, and summarized at the Conference in selected groups, to enable the fullest discussion to be held during the Conference. Prior registration for membership of the Conference is necessary ( $£ 4$ for non-members of the Society of Chemical Industry); application forms can be obtained from the Assistant Secretary, Society of Chemical Industry, 14 Belgrave Square, London, S.W.1, or from the Hon. Secretary of the Conference Committee, E. A. Smith, Acheson Indus. tries (Europe), Ltd., 18 Pall Mall, London, S.W.1. Members of the Conference will receive preprints of all the papers. An exhibition of carbon and graphite will be held in the Department of Chemical Engineering, University College, Gower Street, London, W.C.1, during the Conference.

\section{University News :}

London

THE following appointments in the University of London are announced: Dr. S. D. Elek, reader in bacteriology at St. George's Hospital Medical School, to the chair of bacteriology tenable at that School Dr. F. R. Johnson, lecturer in anatomy in the University of Sheffield, to the readership in anatomy tenable at the London Hospital Medical College; Dr. P. H. Spencer-Silver, to the readership in anatomy tenable at Middlesex Hospital Medical School. 'The title of reader in the University of London has been conferred on : Dr. J. B. E. Baker (pharmacology) in respect of his post at Charing Cross Hospital Medical School ; Mr. E. A. Gellner (sociology) in respect of his post at the London School of Economics and Political Science; Dr. T. W. Glenister (anatomy) in respect of his post at Charing Cross Hospital Medical School; Miss D. M. Hall (chemistry) in respect of her post at Bedford College.

\section{Announcements}

Prof. Arthur Holmes, emeritus professor of geology in the University of Edinburgh, has been awarded the Paul Fourmarier Prize for 1947-56 of the Royal Academy of Belgium.

Mr. G. H. Hinds, electronics advisory officer, British Transport Commission, has been appointed (at the nomination of the Royal Society) a member of the General Board of the National Physical Laboratory. Mr. Hinds is also to serve on the Advisory Committee on High Speed Calculating Machines, Department of Scientific and Industrial Research.

THE U.S. National Science Foundation has announced that its publications are available to all scientists who need them. Lists of publications are available from the Foundation; requests should be addressed to the Publications Office, National Science Foundation, Washington 25, D.C.

REFERENCE was made in Nature of August 3, p. 218, to the translation service being organized by the British Iron and Steel Research Association and the Iron and Steel Institute. Inquiries in connexion with this service should be sent to the Institute, 4 Grosvenor Gardens, London, S.W.1.

THE International Association of Microbiological Societies has at its disposal certain limited funds, which it receives from the International Union of Biological Sciences, for assisting the work of type culture collections of micro-organisms. Curators of such collections who make their type cultures internationally available and require financial help for this purpose are invited to make application, specifying their need, to the secretary of the International Association of Microbiological Societies, Prof. G. Penso, Istituto Superiore di Sanità, Vialo Regina Elena 299, Rome.

THE committee of the Oliver Memorial Fund is to make its annual award of $£ 50$ to a British subject whose original work or services in connexion with blood transfusion is considered to be a notable contribution to the research, organization or donor aspects of that subject. Applications and communications directing attention to suitable candidates must be submitted before September 30 to the honorary secretary, Mrs. F. E. Bedborough, 105 New Park Avenue, London, N.13, to whom all inquiries should be addressed.

THE annual congress of the British Veterinary Association is to be held at Cambridge during August 25-31. All inquiries should be addressed to the Association at 7 Mansfield Streot, Portland Place, London, W.1.

Erratum. In the communication "Amino-Acid Sequence of the $\alpha$-Melanocyte-stimulating Hormone" by Dr. J. Ieuan Harris and Dr. Aaron B. Lerner in Nature of June 29, p. 1346, parts of the sequence indicated on p. 1347, col. 1, have been displaced. The vertical arrows pointing downward should be between 2 and 3,7 and 8 , and 9 and 10 respectively; the lower arrow pointing upwards should be between Arg. and Try. 